\title{
Computed tomography assessment of exogenous surfactant-induced lung reaeration in patients with acute lung injury
}

\author{
Qin Lu*, Mao Zhang ${ }^{2}$, Cassio Girardi ${ }^{3}$, Belaïd Bouhemad ${ }^{1}$, Jozef Kesecioglư ${ }^{4}$, Jean-Jacques Rouby ${ }^{1}$
}

\begin{abstract}
Introduction: Previous randomized trials failed to demonstrate a decrease in mortality of patients with acute lung injury treated by exogenous surfactant. The aim of this prospective randomized study was to evaluate the effects of exogenous porcine-derived surfactant on pulmonary reaeration and lung tissue in patients with acute lung injury and acute respiratory distress syndrome (ALI/ARDS).
\end{abstract}

Methods: Twenty patients with ALI/ARDS were studied (10 treated by surfactant and 10 controls) in whom a spiral thoracic computed tomography scan was acquired before (baseline), 39 hours and 7 days after the first surfactant administration. In the surfactant group, 3 doses of porcine-derived lung surfactant ( $200 \mathrm{mg} / \mathrm{kg} /$ dose) were instilled in both lungs at 0,12 and 36 hours. Each instillation was followed by recruitment maneuvers. Gas and tissue volumes were measured separately in poorly/nonaerated and normally aerated lung areas before and seven days after the first surfactant administration. Surfactant-induced lung reaeration was defined as an increase in gas volume in poorly/non-aerated lung areas between day seven and baseline compared to the control group.

Results: At day seven, surfactant induced a significant increase in volume of gas in poorly/non-aerated lung areas (320 $\pm 125 \mathrm{ml}$ versus $135 \pm 161 \mathrm{ml}$ in controls, $P=0.01)$ and a significant increase in volume of tissue in normally aerated lung areas $(189 \pm 179 \mathrm{ml}$ versus $-15 \pm 105 \mathrm{ml}$ in controls, $P<0.01) . \mathrm{PaO}_{2} / \mathrm{FiO}_{2}$ ratio was not different between the surfactant treated group and control group after surfactant replacement.

Conclusions: Intratracheal surfactant replacement induces a significant and prolonged lung reaeration. It also induces a significant increase in lung tissue in normally aerated lung areas, whose mechanisms remain to be elucidated.

Trial registration: NCT00742482.

\section{Introduction}

Acute respiratory distress syndrome (ARDS) or acute lung injury (ALI) is characterized by hypoxemia, high permeability type pulmonary edema, decreased lung compliance and loss of aeration. Inactivation or deficiency of surfactant is directly involved in ARDS pathophysiology [1]. Pre-clinical experiments show that mechanical ventilation itself can also have a deleterious impact on endogenous surfactant $[2,3]$.

\footnotetext{
* Correspondence: qin.lu@psl.aphp.fr

'Multidisciplinary Intensive Care Unit, Department of Anesthesiology and Critical Care Medicine, Assistance Publique-Hôpitaux de Paris, La Pitié-
Salpêtrière Hospital, UPMC Univ Paris 06, 47-83 boulevard de l'hôpital, 75013 Critical Care Medicine, Assistance Publique-Hôpitaux de Paris, La Pitié-
Salpêtrière Hospital, UPMC Univ Paris 06, 47-83 boulevard de l'hôpital, 75013 Paris, France
}

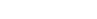

Currently, intratracheal replacement of surfactant is recognized as the standard therapy for premature neonates and children with acute respiratory failure $[4,5]$. In patients with ARDS/ALI, despite the efficacy of surfactant on arterial oxygenation and lung compliance [6], randomized trials have failed to demonstrate a decrease in mortality $[7,8]$. Inadequate doses of surfactant and short treatment duration may account for the lack of beneficial effect on mortality rate $[9,10]$. Administration of natural surfactant rather than synthetic surfactant increases the treatment efficacy and decreases mortality rates in neonates [11]. A recent randomized multicenter trial, however, failed to demonstrate any improvement in mortality following the bolus administration of 
exogenous natural porcine surfactant in patients with early ALI/ARDS [12]. Moreover, oxygenation was not improved by surfactant replacement in this trial. In ARDS/ALI, loss of lung aeration does not have a uniform distribution. In the supine position, aeration loss largely predominates in the lower lobes as a result of external compression by the abdomen and heart $[13,14]$. The deficiency of surfactant also contributes to the loss of lung aeration. As a result, in a vast majority of patients fulfilling the ALI/ARDS criteria, upper lobes remain entirely or partly normally aerated [15]. During mechanical ventilation with positive end-expiratory pressure (PEEP), alveolar recruitment and lung overinflation occur simultaneously in different parts of the lung $[16,17]$. If natural surfactant administered by intratracheal route reaches the distal lung, it should logically reaerate nonaerated lung regions, induce a more homogenous regional distribution of tidal volume and PEEP, and consequently result in a reduction of mechanical ventilation-induced lung injury.

Computed tomography (CT) is the reference method for measuring alveolar recruitment [18] because it provides the possibility of performing a regional analysis taking into account normally and poorly or nonaerated lung regions separately. Alveolar recruitment can be defined as the volume of gas penetrating into poorly and nonaerated lung areas following various therapies such as PEEP, recruitment maneuver or surfactant administration. Based on this CT method, we undertook a prospective randomized study aimed at evaluating the effect of porcine-derived lung surfactant administered by the intratracheal route on lung reaeration in patients with ARDS/ALI.

\section{Materials and methods \\ Study design}

The present study is a part of an international, multicenter, randomized, controlled, open, parallel group study conducted between January 2003 and May 2004 [12]. Twenty mechanically ventilated critically ill patients admitted to the multidisciplinary ICU of La Pitié-Salpêtrière Hospital, University Pierre et Marie Curie, Paris, France, for ALI/ARDS were included in the study and randomized either to the surfactant group (three doses of surfactant in addition to usual care, $n=10$ ) or to the control group (usual care alone, $n=10$ ). Inclusion was restricted to the first 60 hours from the start of mechanical ventilation. Exclusion criteria were: age 18 years or less, acute bronchial asthma attack or suspected pulmonary thrombo-embolism, daily medication for chronic obstructive pulmonary disease at time of admission, need for mechanical ventilation for more than 48 hours continuously within one month prior to the current ventilation period, pneumonectomy or lobectomy, untreated pneumothorax, tracheostomy, surgical procedures under general anesthesia performed within six hours, mean arterial blood pressure below $50 \mathrm{mmHg}$ despite adequate fluid administration and/or need for vasoactive drugs, partial pressure of arterial oxygen $\left(\mathrm{PaO}_{2}\right)$ below $75 \mathrm{mmHg}$ with a fraction of inspired oxygen $\left(\mathrm{FiO}_{2}\right)$ of 1.0 not responding to adjustment of PEEP, head injury, life expectancy less than three months due to primary disease and treatment with any investigational drug within the previous four weeks. The institutional review board of La Pitié-Salpêtrière approved the study protocol. Two informed consents were obtained from each patient or their next of kin: one for inclusion in the international, multicenter, randomized, controlled study conducted between January 2003 and May 2004 [12] and another for the present study.

\section{Surfactant administration}

A freeze-dried natural surfactant isolated from pig lungs (HL-10, Leo Pharmaceutical Products, Ballerup, Denmark; Halas Pharma GmbH, Oldenburg, Germany) composed of approximately 90 to $95 \%$ phospholipids, 1 to $2 \%$ surfactant hydrophobic proteins (surfactant proteins SP-B and SP-C) and other lipids was administered to the patients. The product was delivered as a solution containing $50 \mathrm{mg} / \mathrm{ml}$ of HL-10 (100 ml vials containing $3 \mathrm{~g}$ of HL-10 dispersed in $60 \mathrm{ml}$ warm 37 to $40^{\circ} \mathrm{C}$ saline). Baseline was defined as the time after randomization preceding the first large bolus of surfactant. Up to three doses of HL-10, totalling a maximum cumulative amount of $600 \mathrm{mg} / \mathrm{kg}(200 \mathrm{mg} / \mathrm{kg} /$ dose $)$ were instilled at 0 hour, 12 and 36 hours thereafter. Before each large bolus, patients were sedated and paralyzed. HL-10 was then placed in two $300 \mathrm{ml}$ syringes, with half of the total dose in each. The mechanical ventilator was set on volume control mode with a tidal volume of $6 \mathrm{ml} / \mathrm{kg}$ predicted body weight (PBW), $\mathrm{FiO}_{2}$ of 1.0 and PEEP left unchanged. The patient was turned to one side, the endotracheal tube was clamped at expiratory hold, the mechanical ventilator was disconnected from the patient, and the HL-10 injected into the endotracheal tube as fast as possible. The patient was reconnected to the ventilator, the tube was unclamped and the tidal volume was temporarily increased to $12 \mathrm{ml} / \mathrm{kg} \mathrm{PBW}$ with PEEP reduced to $5 \mathrm{cmH}_{2} \mathrm{O}$ to optimize the pulmonary distribution of HL-10. After five breaths, PEEP was set $5 \mathrm{cmH}_{2} \mathrm{O}$ above pre-HL-10 administration values for 30 minutes, to avoid transient hypoxemia. After all the HL-10 had disappeared from the tube, the patient was turned back to the supine position and the tidal volume was put back to $6 \mathrm{ml} / \mathrm{kg}$ PBW. After a steady state was obtained, the patient was turned to the opposite side and the administration process was repeated to the other lung. 
Computed tomography measurement of lung reaeration Each patient was transported to the Department of Radiology by two physicians (QL, MZ, CG, BB). Spiral CT sections were acquired from the apex to the diaphragm using a spiral Tomoscan SR 7000 (Philips, Eindhoven, The Netherlands) at PEEP $10 \mathrm{cmH}_{2} \mathrm{O}$ at baseline, 39 hours (H39) or within 3 hours after the third bolus of HL-10 for surfactant group and day 7 . During the acquisition, airway pressure was monitored to ensure that PEEP $10 \mathrm{cmH}_{2} \mathrm{O}$ was actually applied. Contiguous axial $5 \mathrm{~mm}$ thick sections were reconstructed from the volumetric data using standard filter in order to avoid an artifactual increase in the hyperinflated compartment [19].

\section{Computed tomography measurement of lung, gas and tissue volumes}

CT data were analyzed using a specifically designed software (Lungview, Institut National des Télécommunications, France) including a color-coding system [20]. The following lung compartments were identified: hyperinflated, made up voxels with CT numbers between -1000 and $-900 \mathrm{HU}$; normally aerated made up voxels with CT numbers between -900 and $-500 \mathrm{HU}$; poorly aerated made up voxels with CT numbers between -500 and $-100 \mathrm{HU}$; nonaerated made up voxels with $\mathrm{CT}$ numbers between
-100 and $+100 \mathrm{HU}$. Using the color-coding system of Lungview, each nonaerated voxel was colored in red, each poorly aerated voxel in light gray, each normally aerated voxel in dark gray and each hyperinflated voxel in white. The overall volume of gas present in both lungs at PEEP $10 \mathrm{cmH}_{2} \mathrm{O}$ was defined as end-expiratory lung volume. Volumes of gas and tissue and hyperinflated lung volume of the whole lung were measured as described in the additional file at baseline, H39 and day 7 [see Additional file 1]. Computed tomography measurement of surfactant-induced lung reaeration

Surfactant-induced lung reaeration was computed on all CT sections according to a method proposed by Malbouisson and colleagues for measuring PEEP-induced alveolar recruitment [18]. Such a method is based on the concept of measuring reaeration not only in nonaerated but also in poorly aerated lung regions on the whole lung. Accordingly, surfactant-induced reaeration was defined as the increase in the volume of gas entering nonaerated and poorly aerated lung regions after three doses of surfactant administration (day 7) compared with baseline. In the control group, lung reaeration was computed as the increase in gas volume within poorly and nonaerated lung regions between day 7 and baseline. The detail regional CT analysis is described in Figure 1.

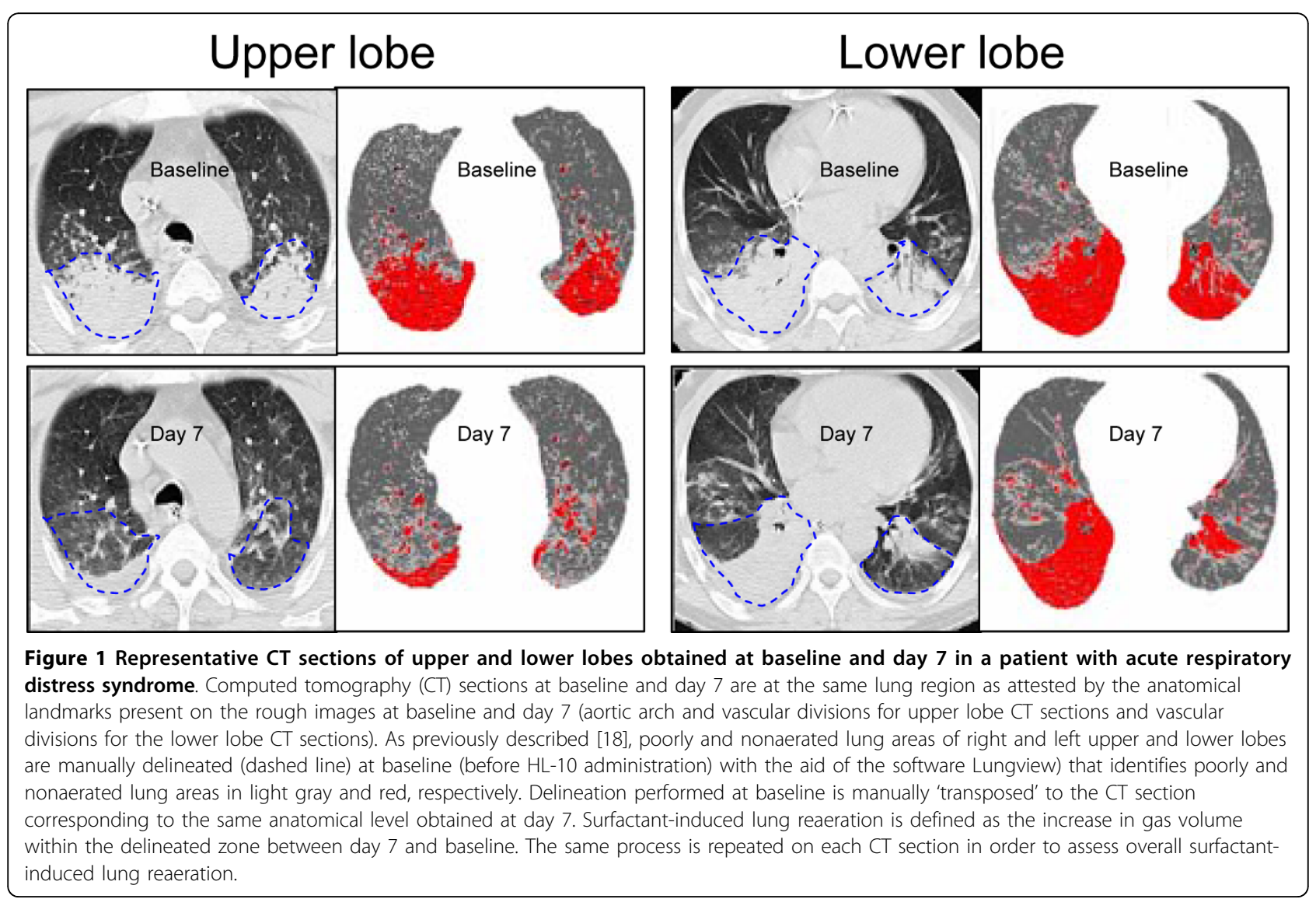




\section{Computed tomography assessment of lung distribution of surfactant}

In both surfactant and control patients, right upper and middle lobes, right lower lobe, left upper lobe and left lower lobe were analyzed separately at baseline and H39. By referring to anatomical landmarks such as pulmonary vessels, fissures, and segmental bronchi, the different pulmonary lobes were identified on each CT section obtained at baseline and H39 and manually delineated using the roller ball of the computer. As the CT scan at H39 in the surfactant group was performed within three hours following the third bolus of HL-10, the increase of volume of tissue at $\mathrm{H} 39$ provided an estimated volume of the third bolus of HL-10. Therefore, the increase in volume of tissue at $\mathrm{H} 39$ was compared with the volume of HL-10 intratracheally administrated. The distribution of surfactant between upper and lower lobes was computed as the increase in lung tissue in each lobe.

\section{Statistical analysis}

The normal distribution of data was verified by a Kolmogorov-Smirnov test. Patients' characteristics and regional changes in volumes of gas and tissue between day 7 and baseline were compared with a chi-squared test or an unpaired bilateral student test. Gas and tissue volumes at baseline and their changes between H39 and baseline within the lobes were compared by Friedman repeated measures analysis of variance on ranks followed by a Tukey test. Correlations between instilled volume of HL10 and increase of tissue volume were made by linear regression. Cardiorespiratory and $\mathrm{CT}$ variables measured at different days were compared between the two groups using a two-way analysis of variance for a repeated factor and a grouping factor. The statistical analysis was performed with Sigmastat 3.1 (Systat Software Inc., Point Richmond, CA, USA). Data were expressed as mean \pm standard deviation or median and interquartile range $(25$ to $75 \%$ ) according to the data distribution. The statistical significance level was fixed at 0.05 .

\section{Results}

Patients

Among the 20 patients, one in the surfactant group died at day 4 from severe hypoxemia. Of patients with ALI/ ARDS, $30 \%$ were related to extrapulmonary sepsis. The overall mortality rate was $30 \%$. As shown in Table 1 , the clinical characteristics and cardiorespiratory parameters at baseline were not different between the control and surfactant patients.

\section{Cardiorespiratory changes in control and surfactant groups}

As shown in Figure 2, $\mathrm{PaO}_{2} / \mathrm{FiO}_{2}$ ratio increased significantly from baseline to $\mathrm{H} 39$ and day 7 in both groups
Table 1 Baseline clinical characteristics of the patients

\begin{tabular}{|c|c|c|c|}
\hline Variables & Control & Surfactant & $P$ value \\
\hline & $(n=10)$ & $(n=10)$ & \\
\hline Male/female & $9 / 1$ & $8 / 2$ & NS \\
\hline Age (years) & $59 \pm 16$ & $62 \pm 12$ & NS \\
\hline SAPS ॥ & $40 \pm 10$ & $41 \pm 10$ & NS \\
\hline LISS & $2.3 \pm 0.4$ & $2.6 \pm 0.5$ & NS \\
\hline Septic shock (\%) & $80 \%$ & $70 \%$ & NS \\
\hline Survival (\%) & $70 \%$ & $70 \%$ & NS \\
\hline \multicolumn{4}{|l|}{ Cause of ALI/ARDS } \\
\hline Bronchopneumonia & 4 & 6 & \\
\hline Aspiration pneumonia & 1 & 1 & NS \\
\hline Lung contusion & 2 & 0 & \\
\hline Sepsis & 3 & 3 & \\
\hline $\mathrm{PaCO}_{2}(\mathrm{mmHg})$ & $38.4 \pm 8.2$ & $37.9 \pm 7$ & NS \\
\hline $\mathrm{PaO}_{2} / \mathrm{FiO}_{2}(\mathrm{mmHg})$ & $200 \pm 63$ & $201 \pm 64$ & NS \\
\hline TV/kg (ml) & $5.7 \pm 0.8$ & $6 \pm 0.9$ & NS \\
\hline RR (breaths/min) & $23 \pm 4$ & $20 \pm 6$ & NS \\
\hline Ppeak $\left(\mathrm{cmH}_{2} \mathrm{O}\right)$ & $32 \pm 5$ & $32 \pm 6$ & NS \\
\hline Pplat $\left(\mathrm{cmH}_{2} \mathrm{O}\right)$ & $23 \pm 4$ & $23 \pm 5$ & NS \\
\hline PEEP $\left(\mathrm{cmH}_{2} \mathrm{O}\right)$ & $9.7 \pm 0.9$ & $9.4 \pm 1$ & NS \\
\hline $\mathrm{Crs}\left(\mathrm{ml} \cdot \mathrm{cmH}_{2} \mathrm{O}^{-1}\right)$ & $38 \pm 12$ & $41 \pm 23$ & NS \\
\hline HR (beats/min) & $110 \pm 23$ & $88 \pm 24$ & NS \\
\hline MAP (mmHg) & $86 \pm 15$ & $87 \pm 20$ & NS \\
\hline
\end{tabular}

$\mathrm{ALI}$, acute lung injury; ARDS, acute respiratory distress syndrome; $\mathrm{Crs}$, compliance of respiratory system; $\mathrm{FiO}_{2}$, fraction of inspired oxygen; $\mathrm{HR}$, heart rate; LISS, lung injury severity score; MAP, mean arterial pressure; NS, not significant; $\mathrm{PaCO}_{2}$, partial pressure of arterial carbon dioxide; $\mathrm{PaO}_{2}$, partial pressure of arterial oxygen; Ppeak, peak airway pressure; PEEP, positive endexpiratory pressure; Pplat, plateau airway pressure; RR, respiratory rate; SAPS II, simplified acute physiology score II; Surfactant, porcine-derived lung surfactant; TV, tidal volume.

Data are expressed as mean \pm standard deviation

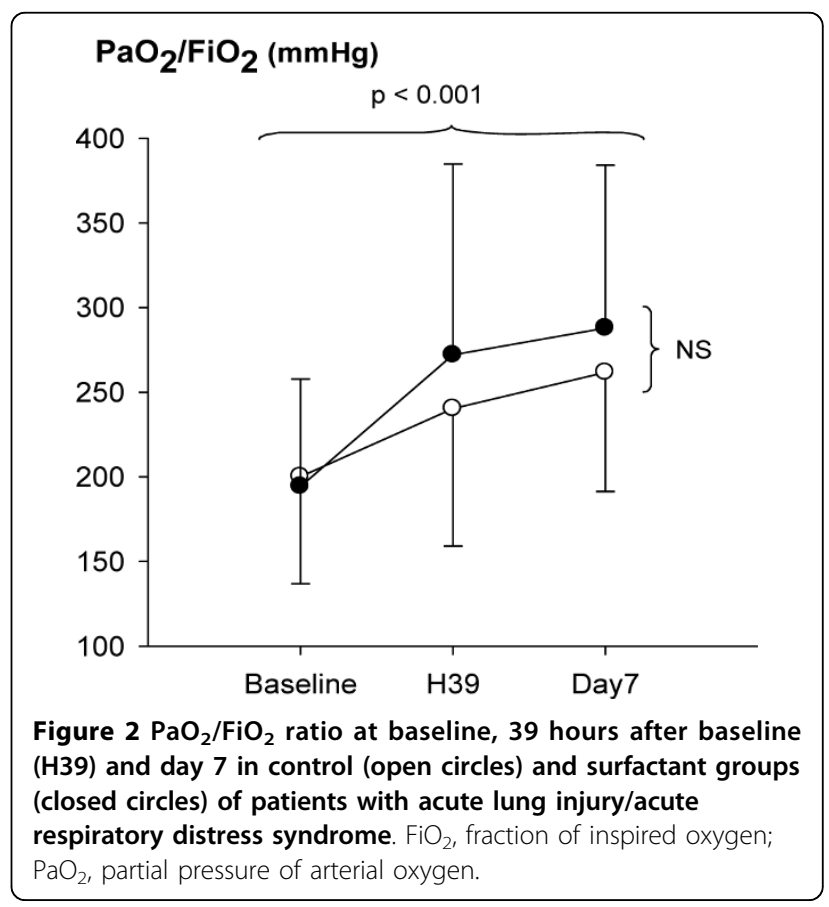


and in similar proportions. All other cardiorespiratory parameters remained unchanged between baseline and day 7 in both groups.

\section{Distribution of $\mathrm{HL}-10$ in the lungs}

The mean volume of HL-10 instilled into the lungs per instillation was $240 \pm 30 \mathrm{ml}$. In the surfactant group, between $\mathrm{H} 39$ (immediately after the third administration of HL-10) and baseline, CT tissue volume increased by $311 \pm 200 \mathrm{ml}$. The increase in tissue volume correlated linearly with the instilled volume $(\mathrm{R}=0.81, P=0.008, \mathrm{Y}$ $=-987+5.4 \mathrm{X})$. As shown in Figure 3, at baseline, $\mathrm{CT}$ gas volume was significantly less in lower lobes than in upper lobes whereas tissue volume was significantly greater in the right upper lobe than in left lower lobe. At H39, gas volume remained unchanged whereas tissue volume significantly increased in similar proportion in the upper and lower lobes.

In the control group, gas volume was not different between baseline and H39. Tissue volume of right lower lobe decreased significantly at H39 compared with the value of baseline (Table 2).

\section{Assessment of lung reaeration after $\mathrm{HL}-10$ replacement}

At baseline and PEEP $10 \mathrm{cmH}_{2} \mathrm{O}$, total lung volume, gas volume and tissue volume were not different between control and surfactant groups. As shown in Figure 4, total gas volume did not change significantly between
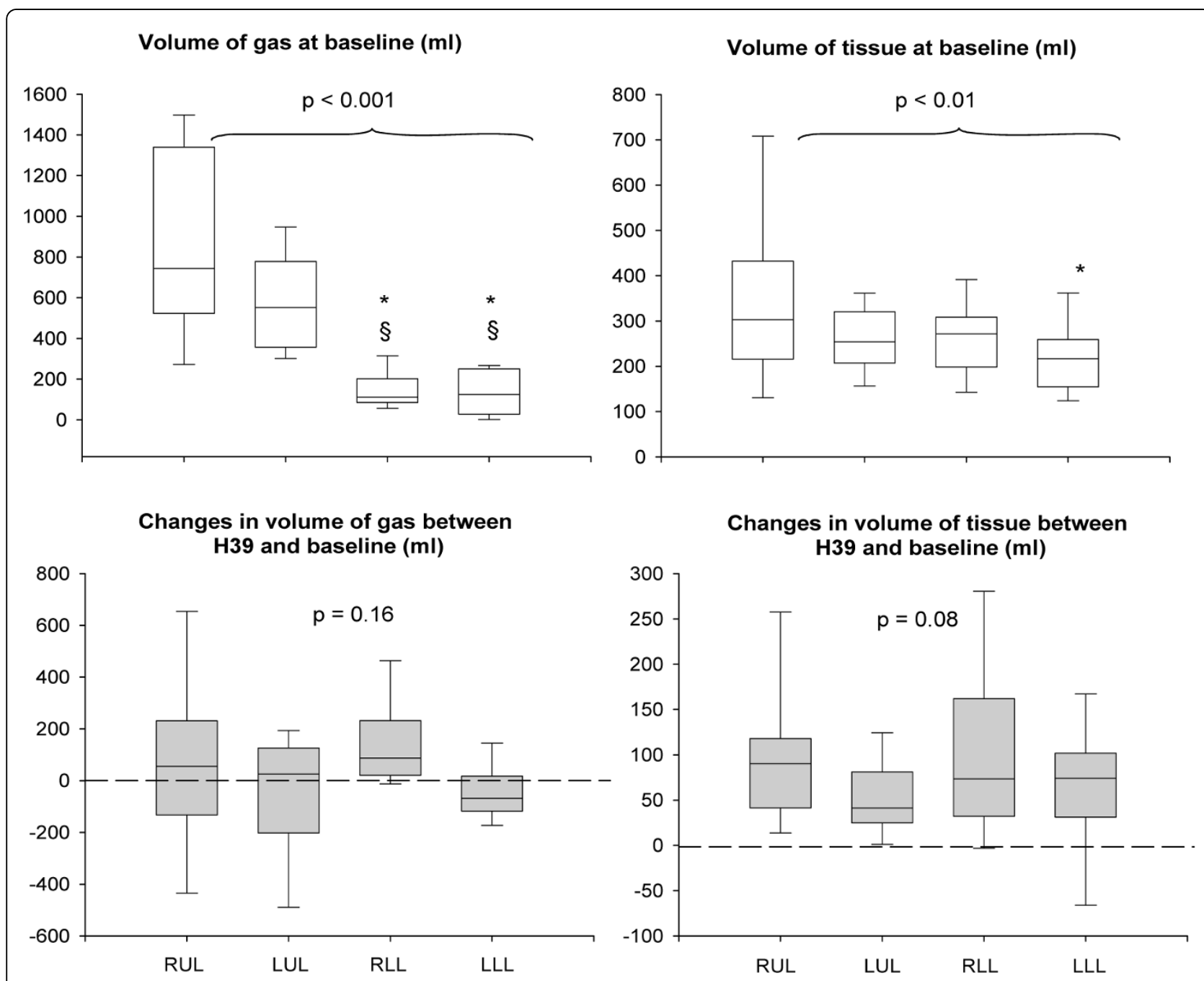

Figure 3 Volumes of gas and tissue at baseline before HL-10 instillation (upper part of the figure) and changes in volume of gas and tissue between H39 (within three hours following the third bolus of HL-10) and baseline (lower part of the figure). Results shown in right upper and middle lobes (RUL), left upper lobe (LUL), right lower lobe (RLL) and left lower lobe (LLL) in patients with acute lung injury/ acute respiratory distress syndrome instilled with $200 \mathrm{mg} / \mathrm{kg}$ of HL-10. Comparisons were performed by Friedman repeated measures analysis of variance on ranks followed by a Tukey test. $P$ values above the horizontal brackets indicate significant difference between RUL, LUL, RLL and LLL using Friedman repeated measures analysis of variance. ${ }^{*} P<0.05$ versus RUL, ${ }^{\S} P<0.05$ versus LUL. 
Table 2 Volumes of gas and tissue at baseline and H39 in the control group of patients

\begin{tabular}{|c|c|c|c|}
\hline & Baseline & H39 & $P$ value \\
\hline \multicolumn{4}{|l|}{ Volume of gas (ml) } \\
\hline Right upper and middle lobe & $864 \pm 440$ & $934 \pm 411$ & NS \\
\hline Left upper lobe & $752 \pm 321$ & $722 \pm 295$ & NS \\
\hline Right lower lobe & $178 \pm 206$ & $241 \pm 244$ & NS \\
\hline Left lower lobe & $142(47-277)$ & $111(23-296)$ & NS \\
\hline \multicolumn{4}{|l|}{ Volume of tissue $(\mathrm{ml})$} \\
\hline Right upper and middle lobe & $317 \pm 115$ & $313 \pm 105$ & NS \\
\hline Left upper lobe & $281 \pm 69$ & $272 \pm 71$ & NS \\
\hline Right lower lobe & $321 \pm 106$ & $275 \pm 87$ & 0.02 \\
\hline Left lower lobe & $299 \pm 89$ & $267 \pm 49$ & NS \\
\hline
\end{tabular}

Data are expressed as mean \pm standard deviation or median and 25 to $75 \%$ interquartile range. H39, CT scan performed 39 hours after baseline. NS, not significant.

baseline, H39 and day 7 in control and surfactant groups. In contrast, HL-10 induced a significant increase in tissue volume at $\mathrm{H} 39$ that persisted at day 7 (interaction $P<0.001)$. The increase in tissue volume between day 7 and baseline correlated linearly with the instilled volume of $\mathrm{HL}-10(\mathrm{R}=0.72, P=0.03, \mathrm{Y}=-1594+$ 7.6X). Hyperinflated lung volume was not different between both groups at baseline, H39 and day 7 .

As shown in Figure 5, in poorly or nonaerated lung regions, gas volume significantly increased at day 7 compared with baseline in both control and surfactant groups. The increase in gas volume at day 7 was significantly greater in the surfactant group than in the control group $(320 \pm 125 \mathrm{ml}$ versus $135 \pm 161 \mathrm{ml}, P=0.01$, Figure $5 \mathrm{a}$ ). In the control patients, tissue volume of poorly or nonaerated lung regions significantly decreased (Figure 5b, $P=0.04$ ) between day 7 and baseline whereas it remained unchanged in surfactant group.

In normally aerated lung regions, gas volume did not change between day 7 and baseline in both groups (Figure 5c). However, HL-10 induced a significant increase in tissue volume at day $7(189 \pm 179 \mathrm{ml}$ versus $-15 \pm 105 \mathrm{ml}, P=0.007$, Figure 5d).

\section{Discussion}

The present study demonstrates that intratracheal administration of porcine-derived surfactant to patients with ALI/ARDS induces a significant lung reaeration of poorly or nonaerated lung regions. This beneficial effect, however, is associated with a significant increase in lung tissue in normally aerated lung areas at day 7 whose mechanisms remain to be elucidated.

Distribution of surfactant within the lung is likely to be an important factor that determines the efficacy of surfactant therapy. Delivery technique and lung morphology influence surfactant distribution. In a previous randomized clinical trial [7], the unsuccessful surfactant treatment was related to the technique of aerosolization that provided less than $10 \%$ distal lung deposition [21]. Intratracheal instillation by a catheter positioned just above the carina has been shown to be much more effective in animals and patients with ARDS $[6,22]$. In patients with ARDS/ALI, the loss of lung aeration does not have a uniform distribution and, in the supine position, dependent and caudal lung regions are virtually nonaerated as a result of external compression by the abdomen and heart $[13,14]$. The distribution of

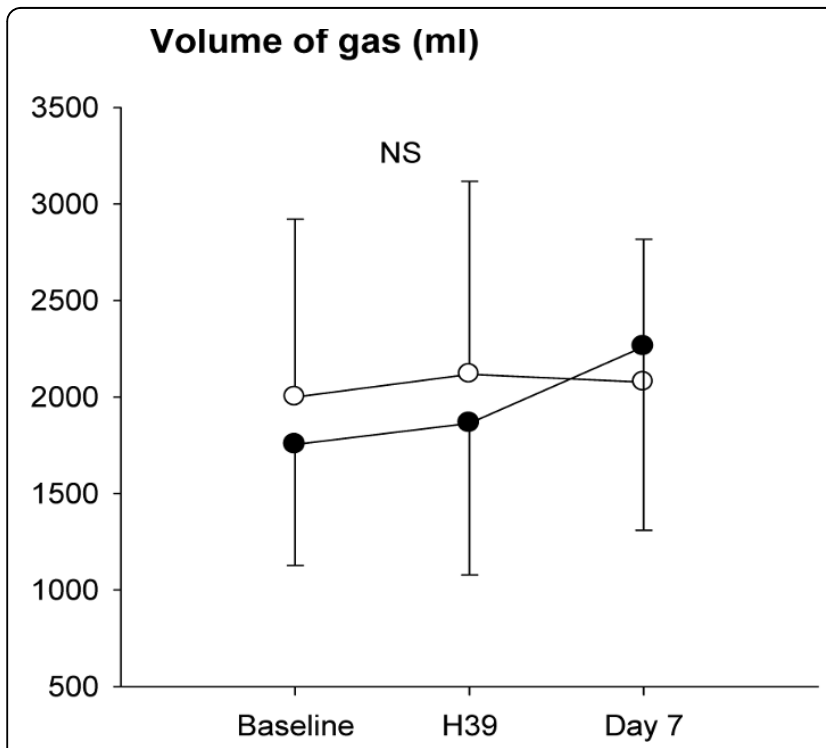

\section{Volume of tissue $(\mathrm{ml})$}

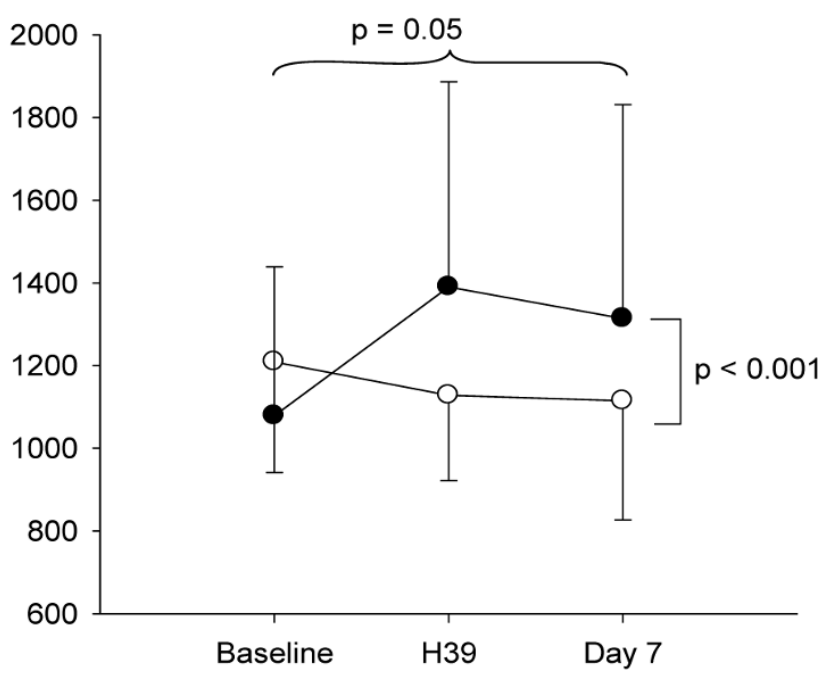

Figure 4 Computerized tomography assessment of total gas and tissue volumes at baseline, 39 hours after baseline (H39) and day 7, in control (open circles) and surfactant groups of patients (closed circles). 

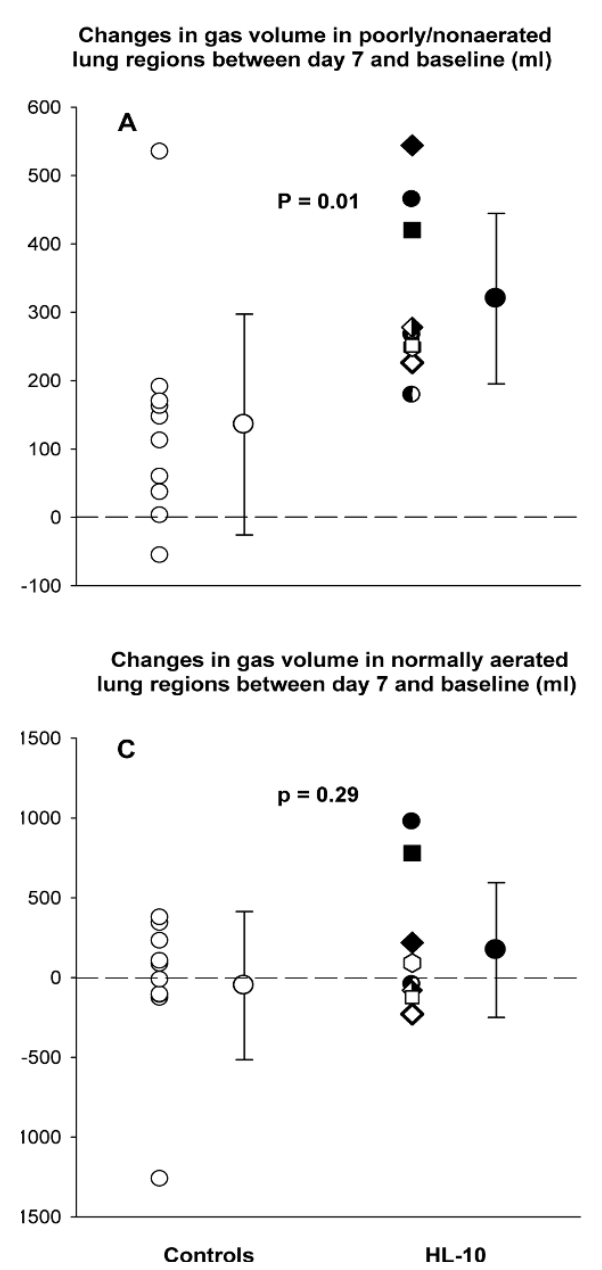

Changes in tissue volume in poorly/nonaerated

lung regions between day 7 and baseline $(\mathrm{ml})$

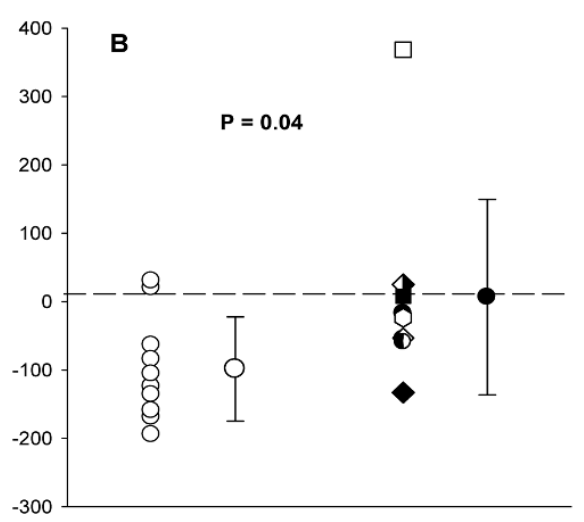

Changes in tissue volume in normally aerated lung regions between day 7 and baseline $(\mathrm{ml})$

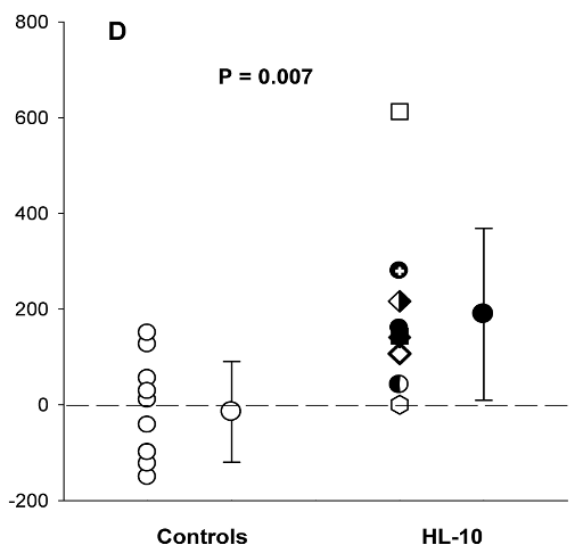

Figure 5 Individual and mean changes in volume of gas and tissue in poorly/nonaerated lung regions (upper part of the figure) and normally aerated lung regions (lower part of the figure). Volume changes were measured on computed tomography scans acquired at baseline and seven days in patients who received either usual care (control, open circles) or usual care plus intratracheal porcine-derived surfactant (HL-10, closed circles). In the surfactant group, each patient is identified by a specific symbol.

exogenous surfactant in aerated and nonaerated parts of the distal lung has never been assessed and it is unknown whether instilled surfactant does penetrate into nonaerated lower lobes. In the present study, the CT scan at H39 in the surfactant group was performed within three hours following the third administration of HL-10. Based on the fact that the tissue volume did not change at $\mathrm{H} 39$ compared with its baseline value in the control group, we can assume that the increase in lung tissue between baseline and H39 in the surfactant group is representative of instilled exogenous surfactant. The present data show that the overall volume of instilled HL-10 was homogeneously distributed between upper and lower lobes and between normally and poorly or nonaerated lung regions (Figure 3). This result demonstrates that the procedure of instillation (successive bolus in right and left lateral positions followed by consecutive recruitment maneuvers) resulted in uniform bilateral surfactant distribution. A predominant distribution of HL-10 in normally aerated lung regions can be ruled out.

Although several randomized trials have failed to demonstrated beneficial effects of exogenous surfactant in adults patients with ARDS in terms of mortality and ventilator-free days $[7,8,23]$, the effect of surfactant therapy on lung aeration had never been evaluated. In the present study, using CT regional analysis of normally and poorly or non-aerated lung regions, a significant higher lung reaeration was evidenced at day 7 in patients treated by surfactant replacement as compared with control patients (Figure 5a). This finding provides evidence that tracheal instillation of HL-10 induces a substantial and prolonged reaeration of poorly or nonaerated lung regions and more specifically of nonaerated 
lower lobes. This encouraging result supports the rationale for exogenous surfactant replacement as indication for lung reaeration in adult patients with ALI/ARDS.

HL-10-induced lung reaeration was, however, associated with a long lasting increase in lung tissue in previously normally aerated lung areas. Its mechanism remains unknown and several hypotheses can be discussed. A delayed alveolar clearance of the large doses of HL-10 administered to aerated lung regions, where endogenous surfactant is already present, is a possible mechanism that could explain the sustained increase in lung tissue. In newborn infants, the surfactant half life is around 35 hours [24]. In patients with ARDS treated by recombinant surfactant, components of exogenous surfactant were retrieved in bronchoalveolar lavage (BAL) two days after initial administration, but were no longer detectable five days later [6]. The dose of surfactant used in the present study was orders of magnitude beyond what was commonly used in neonates, older children and adults. The high volume of phospholipids administered may have prolonged the turn-over time, explaining the persistent increase in lung tissue. Another hypothesis explaining the increase of lung tissue could be an inflammatory reaction resulting from the interaction of HL-10 with active endogenous surfactant present in aerated lung regions [25]. As illustrated in the present study, normally aerated lung regions in ARDS/ALI are characterized by an excess of lung tissue [15] and an increased vascular permeability [26], two abnormalities increasing the vulnerability of lung parenchyma to external aggressions. In these regions, saline diluted HL-10 could induce depletion of endogenous surfactant [27], increased release of TNF and IL-6 in response to overinflation [28] and a resulting increase in lung micovascular permeability. The consecutive influx of albumin into the alveolar space could inactivate further endogenous surfactant [29], and aggravate lung injury. In addition, 720 $\mathrm{ml}$ of saline $(4 \mathrm{ml} / \mathrm{kg} /$ bolus $)$ containing HL-10 were instilled in both lungs over 36 hours. By itself, such an amount of liquid could induce lung injury in experimental normal lungs. Lastly, breakdown products of the phospholipids in surfactant, specifically lysophosphatidylcholine, can provoke inflammation. In this study, BAL after surfactant replacement was not performed. Further study is required to explore the correlation between the presence of inflammatory mediators, components of exogenous surfactant, protein and cells in $\mathrm{BAL}$, and the $\mathrm{CT}$ increase in lung tissue in normally aerated lung areas.

Exogneous surfactant has strong immunomodulatory properties [30-32]. In patients with ARDS, exogenous surfactant therapy decreases IL-6 concentrations in the plasma and BAL of patients with ARDS, suggesting either a direct anti-inflammatory effect or a reduction of ventilator-induced lung stretch [6]. However, in the present study, despite surfactant-induced recruitment of poorly or nonaerated lung regions, CT lung hyperinflation was similar in both groups. Unexpectedly, HL-10induced reaeration was not associated with a significant improvement in arterial oxygenation. Very likely, HL-10 instillation in normally aerated lung regions worsened regional ventilation/perfusion ratios through an increase in lung tissue. In other words, benefit in terms of aeration of poorly or nonaerated regions of the lung was likely to be counteracted by a negative impact of HL-10 on aeration of previously normally aerated lung.

\section{Conclusions}

Although the rationale for exogenous surfactant replacement in patients with ARDS/ALI is strong with some phase II studies showing positive responses [33,34], all clinical phase III studies failed to demonstrate a beneficial effect in terms of mortality and duration of ventilation $[7,8,12]$. Our study demonstrates that non-selective tracheal administration of porcine-derived surfactant reaerates poorly or nonaerated lung regions, but induces a prolonged increase in lung tissue in regions remaining normally aerated; therefore, gas exchange is not improved. Further studies are needed to examine whether a more selective instillation of exogenous surfactant in poorly or nonaerated lung regions would be beneficial in terms of improvement of oxygenation, reduction of mortality and ventilator-free days.

\section{Key messages}

- Intratracheal surfactant replacement reaerates pooly and nonaerated lung regions in patients with ALI/ARDS.

- Intratracheal surfactant replacement induces a prolonged increase in lung tissue in normally aerated lung regions.

\section{Additional material}

Additional file 1: Computed tomography measurement of lung

volumes of gas and tissue. The detail method of computed

tomography measurement of volumes of gas and tissue is described.

\section{Abbreviations}

ARDS: acute respiratory distress syndrome; ALI: acute lung injury; BAL: bronchoalveolar lavage; $\mathrm{CT}$ : computed tomography; $\mathrm{FiO2}$ : fraction of inspired oxygen; IL: interleukin; PaO2: partial pressure of arterial oxygen; PBW: predicted body weight; PEEP: positive end-expiratory pressure; TNF: tumor necrosis factor.

\section{Acknowledgements}

Porcine-derived surfactant was provided by LEO Pharma (HL-10, Leo Pharmaceutical Products, Ballerup, Denmark). Other support was provided from institutional and/or departmental source. 


\section{Author details}

'Multidisciplinary Intensive Care Unit, Department of Anesthesiology and Critical Care Medicine, Assistance Publique-Hôpitaux de Paris, La PitiéSalpêtrière Hospital, UPMC Univ Paris 06, 47-83 boulevard de l'hôpital, 75013 Paris, France. ${ }^{2}$ Department of Emergency Medicine, Second Affiliated Hospital, Zhejiang University, School of Medicine, 88 Jiefang Road, 310009 Hangzhou, China. ${ }^{3}$ Department of Anesthesiology, Federal University of Sao Paulo, Escola Paulista de Medicina, Rua Napoleão de Barros, 715 - $5^{\circ}$ andar, Vila Clementino CEP 04024002 São Paulo, Brazil. ${ }^{4}$ Department of Intensive Care Medicine, University Medical Center Utrecht, Heidelberglaan, 100, 3584 CX Utrecht, The Netherlands.

\section{Authors' contributions}

QL carried out the study and drafted the manuscript. MZ, CG, and BB participated in the study and study analysis. JK participated in the interpretation of the results and gave the advices for improving the manuscript. JJR initiated the study, participated in the design of the protocol and helped to draft the manuscript. All authors read and approved the final manuscript.

\section{Competing interests}

The authors declare that they have no competing interests.

Received: 12 February 2010 Revised: 27 April 2010

Accepted: 15 July 2010 Published: 15 July 2010

\section{References}

1. Hallman M, Spragg R, Harrell JH, Moser KM, Gluck L: Evidence of lung surfactant abnormality in respiratory failure. Study of bronchoalveolar lavage phospholipids, surface activity, phospholipase activity, and plasma myoinositol. J Clin Invest 1982, 70:673-683.

2. Nakamura T, Malloy J, McCaig L, Yao L, Joseph M, Lewis J, Veldhuizen R: Mechanical ventilation of isolated septic rat lungs: effects on surfactant and inflammatory cytokines. J Appl Physiol 2001, 91:811-820.

3. Malloy JL, Veldhuizen RA, Lewis JF: Effects of ventilation on the surfactant system in sepsis-induced lung injury. J Appl Physiol 2000, 88:401-408.

4. Suresh GK, Soll RF: Overview of surfactant replacement trials. J Perinatol 2005, 25(Suppl 2):S40-44.

5. Willson DF, Thomas NJ, Markovitz BP, Bauman LA, DiCarlo JV, Pon S, Jacobs BR, Jefferson LS, Conaway MR, Egan EA: Effect of exogenous surfactant (calfactant) in pediatric acute lung injury: a randomized controlled trial. JAMA 2005, 293:470-476.

6. Spragg RG, Lewis JF, Wurst W, Hafner D, Baughman RP, Wewers MD, Marsh JJ: Treatment of acute respiratory distress syndrome with recombinant surfactant protein C surfactant. Am J Respir Crit Care Med 2003, 167:1562-1566.

7. Anzueto A, Baughman RP, Guntupalli KK, Weg JG, Wiedemann HP, Raventos AA, Lemaire F, Long W, Zaccardelli DS, Pattishall EN: Aerosolized surfactant in adults with sepsis-induced acute respiratory distress syndrome. Exosurf Acute Respiratory Distress Syndrome Sepsis Study Group. N Engl J Med 1996, 334:1417-1421.

8. Spragg RG, Lewis JF, Walmrath $H D$, Johannigman J, Bellingan $G$, Laterre PF, Witte MC, Richards GA, Rippin G, Rathgeb F, Hafner D, Taut FJ, Seeger W: Effect of recombinant surfactant protein C-based surfactant on the acute respiratory distress syndrome. N Engl I Med 2004, 351:884-892

9. Schmidt R, Markart P, Ruppert C, Wygrecka M, Kuchenbuch T, Walmrath D, Seeger W, Guenther A: Time-dependent changes in pulmonary surfactant function and composition in acute respiratory distress syndrome due to pneumonia or aspiration. Respir Res 2007, 8:55.

10. Markart P, Ruppert C, Wygrecka M, Colaris T, Dahal B, Walmrath D, Harbach H, Wilhelm J, Seeger W, Schmidt R, Guenther A: Patients with ARDS show improvement but not normalisation of alveolar surface activity with surfactant treatment: putative role of neutral lipids. Thorax 2007, 62:588-594.

11. Ainsworth SB, Beresford MW, Milligan DW, Shaw NJ, Matthews JN, Fenton AC, Ward Platt MP: Pumactant and poractant alfa for treatment of respiratory distress syndrome in neonates born at 25-29 weeks' gestation: a randomised trial. Lancet 2000, 355:1387-1392.

12. Kesecioglu J, Beale R, Stewart TE, Findlay GP, Rouby JJ, Holzapfel L, Bruins P Steenken EJ, Jeppesen OK, Lachmann B: Exogenous natural surfactant for treatment of acute lung injury and the acute respiratory distress syndrome. Am J Respir Crit Care Med 2009, 180:989-994.

13. Rouby JJ, Constantin JM, Roberto De AGC, Zhang M, Lu Q: Mechanical ventilation in patients with acute respiratory distress syndrome. Anesthesiology 2004, 101:228-234.

14. Malbouisson LM, Busch CJ, Puybasset L, Lu Q, Cluzel P, Rouby JJ: Role of the heart in the loss of aeration characterizing lower lobes in acute respiratory distress syndrome. CT Scan ARDS Study Group. Am J Respir Crit Care Med 2000, 161:2005-2012.

15. Puybasset L, Cluzel P, Gusman P, Grenier P, Preteux F, Rouby JJ: Regional distribution of gas and tissue in acute respiratory distress syndrome. I. Consequences for lung morphology. CT Scan ARDS Study Group. Intensive Care Med 2000, 26:857-869.

16. Nieszkowska A, Lu Q, Vieira S, Elman M, Fetita C, Rouby JJ: Incidence and regional distribution of lung overinflation during mechanical ventilation with positive end-expiratory pressure. Crit Care Med 2004, 32:1496-1503.

17. Vieira SR, Puybasset L, Richecoeur J, Lu Q, Cluzel P, Gusman PB, Coriat P, Rouby JJ: A lung computed tomographic assessment of positive endexpiratory pressure-induced lung overdistension. Am J Respir Crit Care Med 1998, 158:1571-1577.

18. Malbouisson LM, Muller JC, Constantin JM, Lu Q, Puybasset L, Rouby JJ: Computed tomography assessment of positive end-expiratory pressureinduced alveolar recruitment in patients with acute respiratory distress syndrome. Am J Respir Crit Care Med 2001, 163:1444-1450.

19. Reske AW, Busse H, Amato MB, Jaekel M, Kahn T, Schwarzkopf P, Schreiter D, Gottschaldt U, Seiwerts M: Image reconstruction affects computer tomographic assessment of lung hyperinflation. Intensive Care Med 2008, 34:2044-2053.

20. Malbouisson LM, Preteux F, Puybasset L, Grenier P, Coriat P, Rouby JJ: Validation of a software designed for computed tomographic (CT) measurement of lung water. Intensive Care Med 2001, 27:602-608.

21. Lewis JF, McCaig L: Aerosolized versus instilled exogenous surfactant in a nonuniform pattern of lung injury. Am Rev Respir Dis 1993, 148:1187-1193.

22. Henry MD, Rebello CM, lkegami M, Jobe AH, Langenback EG, Davis JM: Ultrasonic nebulized in comparison with instilled surfactant treatment of preterm lambs. Am J Respir Crit Care Med 1996, 154:366-375.

23. Davidson WJ, Dorscheid D, Spragg R, Schulzer M, Mak E, Ayas NT: Exogenous pulmonary surfactant for the treatment of adult patients with acute respiratory distress syndrome: results of a meta-analysis. Crit Care 2006, 10:R41.

24. Torresin M, Zimmermann L, Cogo PE, Cavicchioli P, Badon T, Giordano G, Zacchello F, Sauer PJ, Carnielli VP: Exogenous surfactant kinetics in infant respiratory distress syndrome: A novel method with stable isotopes. Am J Respir Crit Care Med 2000, 161:1584-1589.

25. Grotberg JB, Halpern D, Jensen OE: Interaction of exogenous and endogenous surfactant: spreading-rate effects. J Appl Physiol 1995, 78:750-756.

26. Sandiford P, Province MA, Schuster DP: Distribution of regional density and vascular permeability in the adult respiratory distress syndrome. Am J Respir Crit Care Med 1995, 151:737-742.

27. Hafner D, Germann PG: A rat model of acute respiratory distress syndrome (ARDS) Part 2, influence of lavage volume, lavage repetition, and therapeutic treatment with rSP-C surfactant. J Pharmacol Toxicol Methods 1999, 41:97-106.

28. Stamme C, Brasch F, von Bethmann A, Uhlig S: Effect of surfactant on ventilation-induced mediator release in isolated perfused mouse lungs. Pulm Pharmacol Ther 2002, 15:455-461.

29. Strohmaier W, Trupka A, Pfeiler C, Thurnher M, Khakpour Z, GippnerSteppert C, Jochum M, Redl H: Bilateral lavage with diluted surfactant improves lung function after unilateral lung contusion in pigs. Crit Care Med 2005, 33:2286-2293.

30. van Putte BP, Cobelens PM, van der Kaaij N, Lachmann B, Kavelaars A, Heijnen $C J$, Kesecioglu J: Exogenous surfactant attenuation of ischemiareperfusion injury in the lung through alteration of inflammatory and apoptotic factors. J Thorac Cardiovasc Surg 2009, 137:824-828.

31. Wemhoner A, Rudiger M, Gortner L: Inflammatory cytokine mRNA in monocytes is modified by a recombinant (SP-C)-based surfactant and porcine surfactant. Methods Find Exp Clin Pharmacol 2009, 31:317-323.

32. Erpenbeck VJ, Fischer I, Wiese K, Schaumann F, Schmiedl A, Nassenstein C, Krug N, Hohlfeld JM: Therapeutic surfactants modulate the viability of 
eosinophils and induce inflammatory mediator release. Int Arch Allergy Immunol 2009, 149:333-342.

33. Kesecioglu J, Schultz MJ, Maas JJ, De Wilde RB, Steenken El, Lachmann B: Treatment of acute lung injury and ARDS with surfactant is safe [abstract]. Am J Respir Crit Care Med 2004, 169:A349.

34. Gregory TJ, Steinberg KP, Spragg R, Gadek JE, Hyers TM, Longmore WJ, Moxley MA, Cai GZ, Hite RD, Smith RM, Hudson LD, Crim C, Newton P, Mitchell BR, Gold AJ: Bovine surfactant therapy for patients with acute respiratory distress syndrome. Am J Respir Crit Care Med 1997, 155:1309-1315.

doi:10.1186/cc9186

Cite this article as: Lu et al: Computed tomography assessment of exogenous surfactant-induced lung reaeration in patients with acute lung injury. Critical Care 2010 14:R135.

Submit your next manuscript to BioMed Central and take full advantage of:

- Convenient online submission

- Thorough peer review

- No space constraints or color figure charges

- Immediate publication on acceptance

- Inclusion in PubMed, CAS, Scopus and Google Scholar

- Research which is freely available for redistribution

Submit your manuscript at www.biomedcentral.com/submit 